Fabio Rambelli

\title{
7 In the Footprints of the Buddha: Ceylon and the Quest for the Origin of Buddhism in Early Modern Japan - A Minor Episode in the History of the Japanese Imagination of India
}

Throughout the premodern era, many Japanese created representations of India and of India's relations to Japan. References to India (often referred to with its Buddhist name, Tenjiku) can be found in a wide variety of texts, including origin narratives about deities, sacred places, professions and professional tools. A striking aspect of the Japanese imagination about India is that many sources claim that significant aspects of Japan and Japanese culture originated in India: mountains flying from India to Japan, Japanese kami being reincarnations of Indian people, professional tools coming in from India; even some samurai clans claimed that they were carrying out in Japan the struggle opposing the devas to the asuras (of course, on the side of the former). It goes without saying that most of this was largely imaginary and owed very little to actual interactions. In fact, a very few people from India are known to have ever reached Japan, and we have no certain information about any Japanese ever reaching India until the sixteenth century. Thus, Japanese knowledge about India was essentially based on the Chinese Buddhist monk Xuanzang's (ca. 602-664) account of his travels there in the seventh century, and on additional information scattered in the Buddhist canon. Considering this lack of direct communication, the fascination of the Japanese for India is even more striking. I have elsewhere proposed the term "Indianization" to describe the impact of Indian culture to Japan - which goes beyond more or less imaginary origins. For instance, knowledge of Sanskrit was influential in the developing of the kana syllabaries in the eleventh and twelfth centuries; Indian narrative elements concurred in the development of classical and medieval Japanese literature; knowledge of political theories and of the caste system contributed to the organization of premodern Japanese society; and Indian ideas about the sacred, not limited to Buddhism, contributed to the development of Japanese religiosity. ${ }^{1}$

1 For an overview of some these aspects, see Rambelli (2014).

Ә Open Access. (C) 2019 Fabio Rambelli, published by De Gruyter. (cc) BY-NC-ND This work is licensed under a Creative Commons Attribution-NonCommercial-NoDerivatives 4.0 International License. 
In the Edo period (1600-1868), the Japanese imagination about India began to change. The development of alternative and competing representations of the world (Confucian and Sinocentric, European and Eurocentric, Nativist and Japanocentric), together with increasingly numerous and vocal anti-Buddhist discourses, concurred to relativizing India's role and prestige. This process was further compounded by the arrival of new information on India, mostly brought by Europeans (at first the Jesuits, and later, after the self-closure of Japan to foreigners in the early seventeenth century, by the Dutch). This new information forced the Japanese to revise their own knowledge about India which, as we have seen, was based on texts written many centuries before.

Western sources brought new information about places; about practices (kingship, caste system, etc.); and about the enormous wealth of India - little of which was mentioned in the Buddhist texts. The westerners also made it known to the Japanese that India was gradually falling under the control of western powers (Portugal, France, Holland, and later England). All of this contributed to the loss of prestige of Buddhist texts (as their information was not reliable) and ultimately of Buddhism itself (which many Japanese intellectuals saw as one of the causes of India's decline and colonization by barbarians).

A major discrepancy between western and Japanese knowledge of India concerned Buddhism. Initially, westerners treated Buddhism as one of many forms of world's paganism or heathenism. But when the Japanese (and others in Asia with whom the Europeans had contacts) kept insisting that Buddhism was a specific religion that originated in north India, westerners were puzzled. There was no cult of Buddha in India, and northern India in particular was largely Muslim. Westerners had no information about the sacred places of the Buddha - which, we should remember, were "rediscovered" in the second half of the nineteenth century by British, German, and Nepalese archeologists. Yet, the Europeans began to realize the similarities among various religious traditions in East Asia, Southeast Asia, Tibet, Mongolia, and Śrī Lankā; by the late seventeenth century, they knew that those countries shared the same religious framework, even though they didn't share a single sacred language and unified teachings, rituals, and representations. But the similarities were obvious enough. ${ }^{2}$ Yet, the origins of this vast religious tradition were still unclear.

This chapter explores what happens when different sets of geographical and cultural knowledge meet by addressing the ensuing processes of interpretation, validation, and comparison with previous knowledge. The case in point

2 On the history of the western discovery of Buddhism, see de Lubac (1952), Droit (1997), App (2012), Allen (2002), Almond (1988). 
is the role of Śrī Lañkā (at the time known as Ceylon) in the formation of the western discourse about Buddhism - a discourse that had repercussions also as far as Japan.

\title{
7.1 Ceylon and the Origin of Buddhism
}

All local information from several regions in Asia pointed toward India as the original place of Buddhism, and Ceylon was the only place in the Indian subcontinent where Buddhism was actually practiced (as known by the Europeans in the seventeenth and eighteenth centuries); since westerners had colonized the island, western sources began to circulate in Japan indicating a strong connection between Ceylon and the Buddha.

A clear example is a text by the Japanese Confucian scholar and politician Arai Hakuseki (1657-1725), entitled Sairan igen and written in 1713, which contains descriptions of the world's countries drawn from a wide range of Chinese sources combined with more recent information from Europe. The latter was mostly acquired in conversations that Hakuseki had with the Italian Jesuit priest Giovanni Battista Sidotti (1668-1714), who entered Japan illegally in 1708 and was kept prisoner in Edo (present-day Tokyo) until his death. This text reports that in Ceylon there are footprints of the Buddha, and a temple enshrines a magnificent statue of a reclining Buddha together with a relic of a tooth of the Buddha. ${ }^{3}$ This information appears to be based, at least in part, on an account given by the Chinese monk Faxian (337-ca. 422), who stayed in the island for two years around 412-414 in the last leg of his long voyage in India (399-414):

\begin{abstract}
When Buddha came to this country, wishing to transform the wicked nagas, by his supernatural power he planted one foot at the north of the royal city, and the other on top of a mountain, the two being fifteen yojanas apart. Over the footprint at the north of the city the king built a large tope, 400 cubits high, grandly adorned with gold and silver, and finished with a combination of all the precious substances. By the side of the tope he further built a monastery, called the Abhayagiri, where there are (now) five thousand monks. There is in it a hall of the Buddha, adorned with carved and inlaid work of gold and silver, and rich in the seven precious substances, in which there is an image (of Buddha) in green jade, more than twenty cubits in height, glittering all over with those substances, and having an appearance of solemn dignity which words cannot express. ${ }^{4}$
\end{abstract}

3 Arai Hakuseki 新井白石, Sairan igen 采覧異言.

4 Faxian, Foguoji, also known as Kaoseng Faxian zhuan, in T. vol. 51 no. 2085, pp. 857-866; English translation by James Legge ([1886] 1965, 102). 
Note that Faxian does not mention a statue of Buddha's Parinibbana, which probably did not exist at the Abhayagiri monastic complex in Anuradhapura (the largest sculpture of Buddha's Parinibbana is located in the Gal temple in Polonnaruva); Hakuseki may have combined additional, more recent information to Faxian's classic description when he wrote about a reclining Buddha statue. ${ }^{5}$

After this passage, Hakuseki adds, "it is said that this [Ceylon] is the place of Buddha's nirvana." ${ }^{6}$ Hakuseki included the same information in another text he wrote on international matters, Seiyō kibun $(1715)^{7}$; there seems to have been a perception that Buddha left his footprint in the island at the moment of his nirvana. This might be due to an inference made by foreign travelers, who associated the footprint of the Buddha, and thus a visit of the Buddha to Ceylon, with the numerous representations of the Buddha's Parinibbana present in the country.

It is interesting to note here that Hakuseki and other early modern authors did not quote from the account of Śrī Lañkā made by the Chinese monk Xuanzang (ca. 602-664) in his Da Tang xiyu ji (646) ${ }^{8}$; Xuanzang, however did not actually travel to the island, but limited himself to report stories and information he had acquired in India.

We may also note here in this connection that prior to Arai Hakuseki's works, Ceylon was mentioned at least three times in an important text by geographer Nishikawa Joken (1648-1724), the Zōho Ka-i tsūshōkō (1708): first as Keiran, ${ }^{9}$ then as Sairon or Seira, ${ }^{10}$ and finally as Seiron, where the author writes: “3,870 leagues by sea from Japan. It is an island; it has a ruler who performs punishments (shioki suru). It is a hot country, and its people look like the Siamese. It is a despicable (iyashiki) land. It is in the ocean of South India." 11 Interestingly, Nishikawa does not mention any connection between the island and the origin of Buddhism.

5 Faxian, however, did mention a relic of Buddha's tooth: Faxian, in Legge (1965, 104-106).

6 Arai Hakuseki, Sairan igen, p. 837a.

7 Arai Hakuseki, Seiyō kibun 西洋記聞, p. 44.

8 Xuanzang, Da Tang xiyu ji, in T vol. 51, n. 2087, pp. 932b-934c; see The Great Tang Dynasty Record of the Western Regions, translated by Li Rongxi (1996, 323-333). Xuanzang does not mention any statue of a reclining Buddha.

9 See http://archive.wul.waseda.ac.jp/kosho/i13/i13_00581/i13_00581_0004/i13_00581_ 0004_p0009.jpg, last accessed 30 January 2018.

10 See http://archive.wul.waseda.ac.jp/kosho/i13/i13_00581/i13_00581_0004/i13_00581_ 0004_p0011.jpg, last accessed 30 January 2018.

11 See http://archive.wul.waseda.ac.jp/kosho/i13/i13_00581/i13_00581_0004/i13_00581_ 0004_p0016.jpg, last accessed 30 January 2018. For a print edition of this text, see Zōho Ka-i tsūshōkō 増補華夷通商考 (Revised and Expanded Considerations on Trade with Civilized and Barbarian Peoples) by Nishikawa Joken 西川如見 ([1944] 1988). 
The superposition of Buddhist sacred places onto Ceylon's geography contributed to the misunderstanding that the island was one of the original sacred places of Buddhism. Particularly important in this process is the identification of Adam's Peak with Mount Lañkā (Jp. Ryōgasen), the place where the Buddha supposedly taught the Lañkāvatārasūtra. A map of India (Figure 7.1) included in Hirata Atsutane's Indo zōshi (Atsutane worked on this text for six years, from 1820 to 1826), shows Adam's Peak (Jp. Atamusuzan) in the southeastern part of Ceylon (Figure 7.2); a note in the map says: "Adam['s Peak] was called in the past Mount Lan̉kā [Jp. Ryōgasen]; place in which Sākyamuni preached scriptures.”

Hirata Atsutane apparently based his map on information received from Holland. Before him, the polymath and western studies scholar Shiba Kōkan (1747-1818) had painted Adam's Peak in 1808 (Figure 7.3), which he understood as being a different name for the Vulture Peak (Jp. Ryōjusen, Sk. Gṛdhrakūṭa), the sacred place of Buddhism where the Buddha is believed to have preached some of the most influential scriptures, including the Lotus Sutra. ${ }^{12}$

Shiba Kōkan's painting was, in turn, based on Dutch precedents, such as the painting presented in Figure 7.4.

This is an indication of the confusion generated by attempting to map western knowledge (which, in the case of Buddhism, was largely wrong) onto received Japanese knowledge.

The misperception of Śrī Lañkā as being directly connected with the life of the Buddha continues in Japan well into the Meiji period (1868-1912), the time of the early phases of Japan's modernization. The well-known and influential supporter of modernization as westernization, Fukuzawa Yukichi (1835-1901), published in 1869 a compendium of world geography, entitled Sekai kunizukushi. In it we read: "Next, at the southern tip of India Ulterior [Hindustan] there is the island of Ceylon. This is also a British possession, and has good harbors. This island is the birthplace of Sākyamuni."13

It is not clear where Fukuzawa acquired this information, but an obvious source (albeit, perhaps, an indirect one in the case of Fukuzawa) comes to mind: Marco Polo's Travels (Italian Il milione). The Travels is the first text to present to the west a fairly accurate account of the life of the Buddha Saakyamuni, whom Polo calls Sagamoni Borcan; this account was probably based on information he had gathered in Ceylon (which he calls Seilan). ${ }^{14}$ Marco Polo describes the

12 On Shiba Kōkan, see Keene (1969).

13 Fukuzawa Yukichi 福沢諭吉, Sekai kunizukushi 世界国尽 (Compendium of All Countries of the World), p. 596a.

14 Borcan is the Italianized form of the Mongolian Burkhan, "deity," used by the Mongolians to refer to the Buddha. 


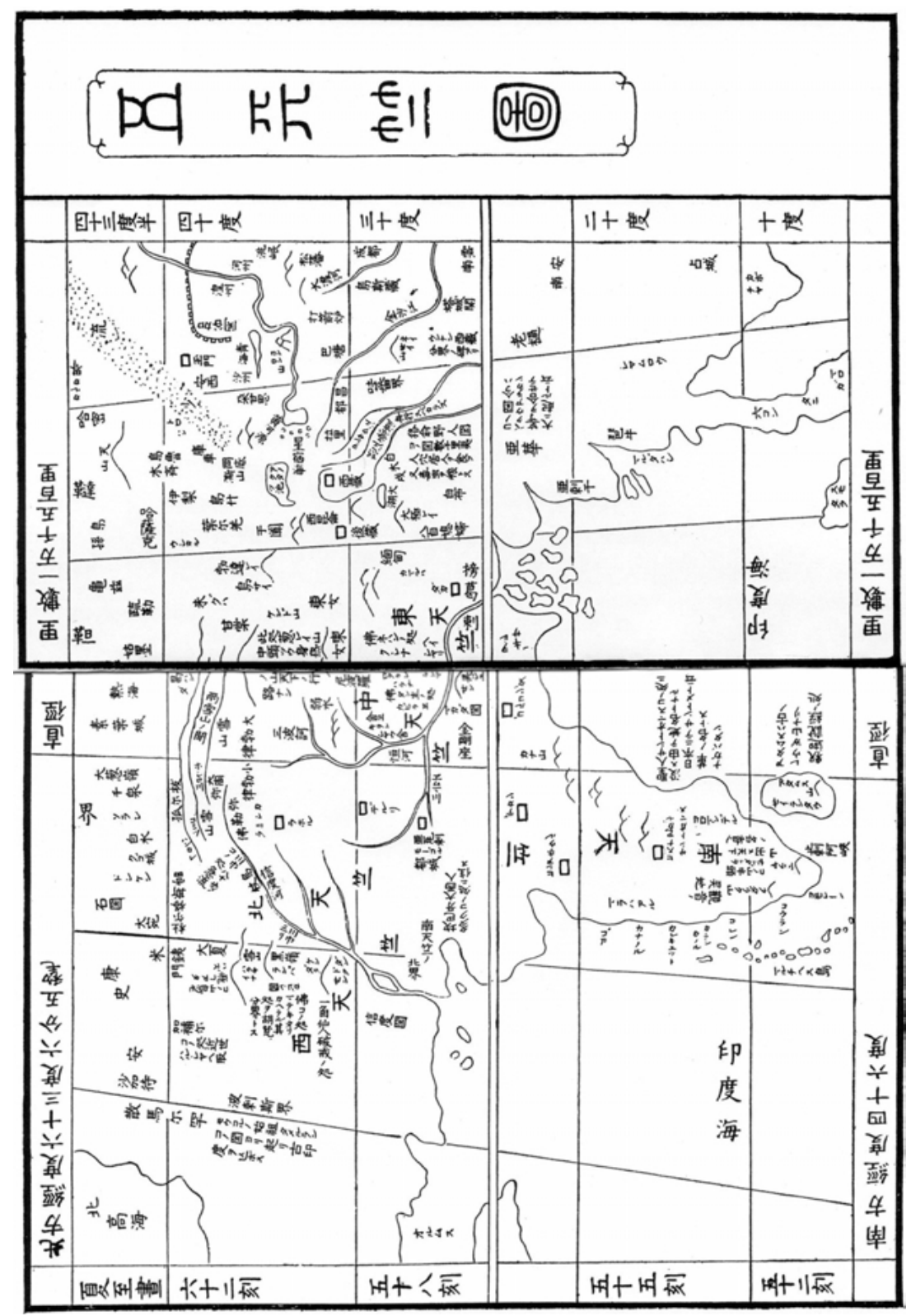

Figure 7.1: Map of India by Hirata Atsutane 平田篤胤, from Indo zōshi 印度蔵志, in Hirata Atsutane (1977, vol. 11, 26-27). 


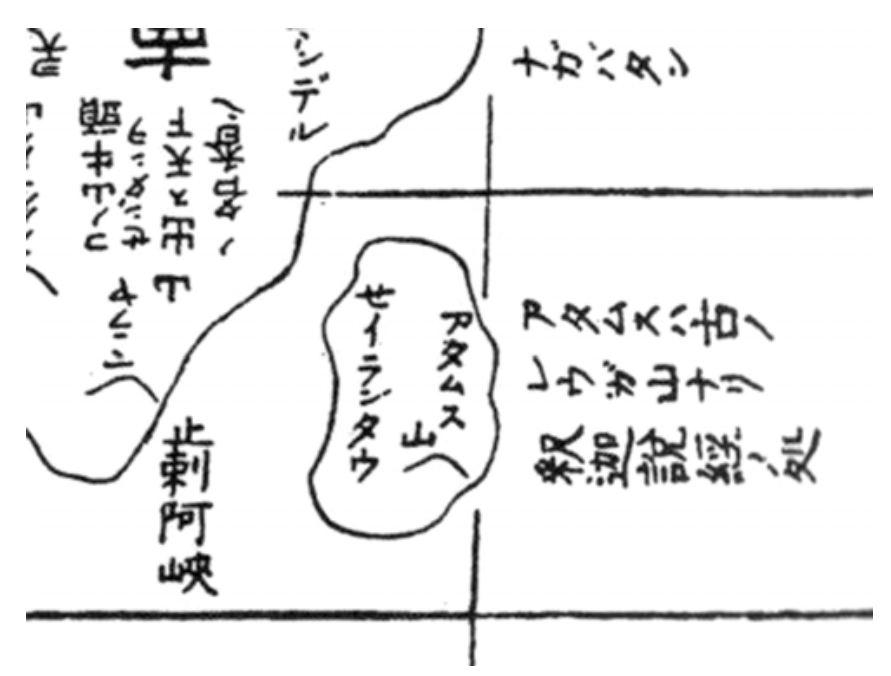

Figure 7.2: Ceylon in Hirata Atsutane's map of India (detail), from Indo zōshi 印度蔵志, in Hirata Atsutane (1977, vol. 11, 26-27).

miraculous birth of Sagamoni, his noble upbringing, and his ascetic life and final demise. At the end, Polo writes: "And this befel in the Island of Seilan in India." 15 The Venetian also mentions Adam's Peak; he writes that the Saracens consider it the burial place of Adam, the first man, but he also adds that "the idolaters" [i.e., the Buddhists] say it is Sagamoni Borcan's tomb. ${ }^{16}$

It is important to recall here that the sacredness of that mountain in Śri Lañkā is recognized by several religious traditions: in addition to the Buddhists, Hindus, Muslims, and Christian also have attributed to it a role in their own religious narratives. Adam's Peak is called the Mountain of Serendib by the Arabs; Hindu sources refer to it as Srī Pāda and claim that the footprint is Siva's. The mountain, the footprint, and the devotional practices associated to it, involving Muslims and "idolaters" (both Buddhists and Shaivites), are described by Ibn Battuta in his travel records. ${ }^{17}$

In the 1600s the Portuguese arrived to Ceylon and added another layer to the religious palimpsest of the sacred mountain. A Portuguese traveler,

15 See Marco Polo, The Travels of Marco Polo, Book 3, Chapter 15.

16 See Marco Polo, The Travels of Marco Polo, Book 3, Chapter 15.

17 See Holt (2011, 116-117). See also Ibn Battuta's description of Śrī Pāda in The Travels of Ibn Batuta, translated by Rev. Samuel Lee (1829, 183-192). 


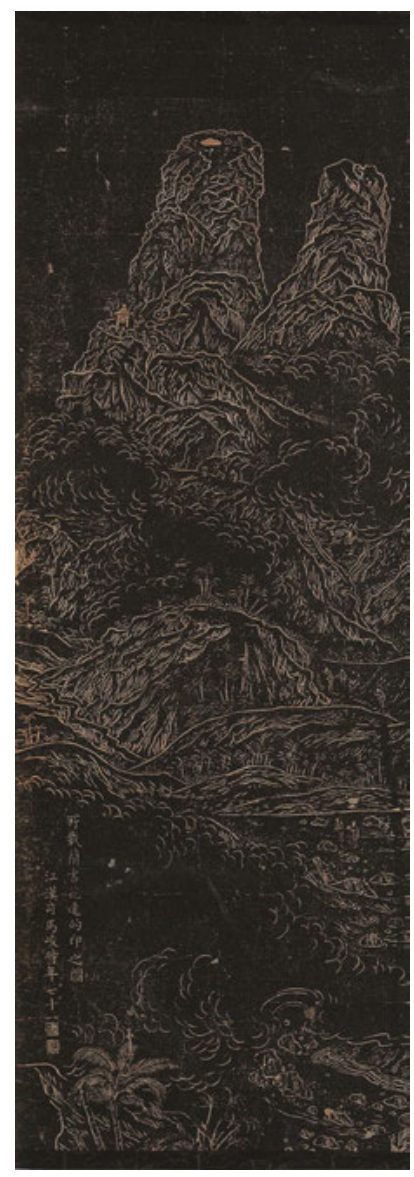

Figure 7.3: Shiba Kōkan, Vulture Peak. From Kōbe Shiritsu Hakubutsukan $(2001,57)$.

Constantino de Sá de Miranda (active 1638-1644), wrote that the footprint was produced not by "Buddum as the Chingalas believe," but by Saint Thomas the Apostle. $^{18}$

Before Constantino de Sá de Miranda, a Portuguese historian, Diogo do Couto (ca. 1542-1616), argued that what the Singhalese call Buddum was in fact Prince Josafat, one of the protagonists of the famed medieval tale of Barlaam

18 Quoted in Holt $(2011,172)$. 


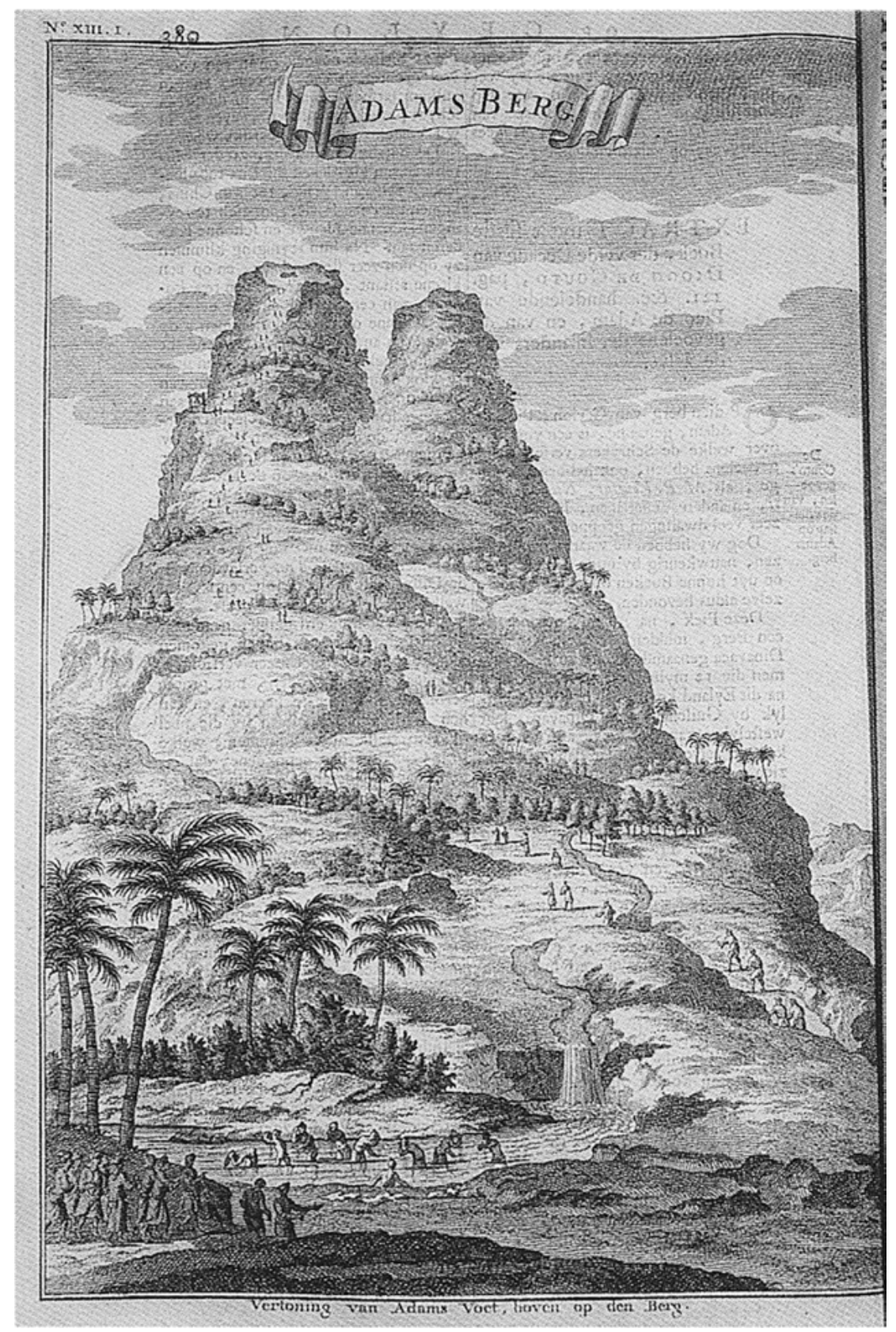

Figure 7.4: Adam's Peak by François Valentijn (Holland, 1666-1727), painted in 1724-1726. From Kōbe Shiritsu Hakubutsukan $(2001,57)$. 
and Josafat. Apparently, Diogo do Couto had noticed the striking resemblance between Sagamoni's life as told by Marco Polo and the legend of Josafat. ${ }^{19}$

This understanding that Buddha was closely related to Ceylon became fairly common in Europe for a couple of centuries. In 1691 Simon de la Loubère, envoy of the king of France Louis XIV on the third French mission to Siam, reported that the religion of Siam had come from Ceylon, and that SommonaCodom, that is, the Buddha Sākyamuni, "was the Son of a King of the Island of Ceylon." 20 The English sailor Robert Knox (1641-1720), in An Historical Relation of the Island Ceylon, in the East-Indies of 1681, wrote: "The Mountain is at the South end of the Countrey, called Hammalella, but by Christian People, Adam's Peak, the highest in the whole Island; where, as has been said before, is the Print of the Buddou's foot, which he left on the top of that Mountain in a Rock, from whence he ascended to Heaven;" that the mark on Adam's Peak is the "foot-step of their great idol Buddou." ${ }^{21}$ Later, Michel-Jean François Ozeray, the author of Recherches sur Buddou or Bouddou, Instituteur religieux de l'Asie orientale (1817), perhaps the first European book in which the Buddha was described as "a distinguished philosopher, a wise man born for the happiness of his fellow creatures and the good of humanity,"22 wrote that Buddou was born in Ceylon "Son of a king (of Ceylon, according to Japanese tradition)." ${ }^{23}$ It is worth recalling here that India came to be generally recognized in West as the place of origin of Buddha and Buddhism only by the late $1840 \mathrm{s.} .^{24}$ Thus, it is less surprising to read Ozeray writing about Ceylon as the birthplace of Buddha than to find his claim that this information is based on a "Japanese tradition." One cannot but wonder about the possibility that wrong information about Ceylon as the birthplace of Buddha, brought to Japan by the Europeans, had somehow made its way back to Europe and was being quoted by European authors as based on Japanese sources.

19 On the medieval Christian legend of Barlaam and Josaphat, which is a transformation of the standard, classical account of the life of the Buddha, after a long and complex cultural drift (Sanskrit to Persian to Armenian to Greek to Latin to the vulgar languages of medieval Europe), see Cesaretti and Ronchey (2012) and Lopez and McCracken (2014). On Diogo do Couto's interpretation, see da Lourinhã (1963).

20 In Simon de la Loubère, Du Royaume de Siam, p. 525.

21 Robert Knox, An Historical Relation of the Island Ceylon, in the East-Indies, p. 81; see also pp. 3, 72 .

22 Michel-Jean François Ozeray, Recherches sur Buddou or Bouddou, Instituteur religieux de l'Asie orientale, p. 40.

23 Michel-Jean François Ozeray, Recherches sur Buddou or Bouddou, Instituteur religieux de l'Asie orientale, p. 51.

24 See Almond $(1988,22)$. 
In any case, early modern Europeans had only a vague and imprecise set of information about Buddha and his relations to Ceylon: some sources claimed that Buddha was born there, others that the island was his death place. These pieces of information made their way to Japan, where they influenced late premodern and early modern understanding of Buddhist history and geography.

\subsection{A Geographical Short-Circuit}

We have here a case of intellectual short-circuit, in which insufficient information (on Buddhism), combined with wrong or imprecise inferences (about Ceylon), but stated with strong conviction, generate misunderstandings. However, we should also note that this early-modern global discourse about Ceylon's role in the origin of Buddhism is not completely far-fetched. Buddhist chronicles of Śrī Lankā report that the Buddha visited the country three times: the third time, in particular, he visited Kelaniya (Sk. Kalyānī) upon invitation by the nāga king Maniakkhika; on that occasion, the Buddha went to Mt. Sumanakūta (Sin. Samanola) and left his footprint there. ${ }^{25}$ As we have seen, the Chinese traveler Faxian (but not Xuanzang) also mentions a mountain in Ceylon where the Buddha left his footprint. After Faxian, other Buddhist sources in East Asia, in particular those associated with Tang period esoteric Buddhism, also refer to Śrī Lan̉kā and its sacred mountain. ${ }^{26}$

We should also note that there is another close association between the Buddha and Śrī Lañka, namely, the "fact" that Buddha exposed the Laṇkāvatārasūtra on Mt. Lañkā, the residence of the rākṣasa (demon) Rāvaṇa ${ }^{27}$ who, incidentally, happens to be the negative hero of the Indian epic tale Rāmāyaña. As we have seen, Mt. Lañkā is, in fact, an old appellation of the mountain later called Adam's Peak and Śrī Pāda. This information is partly present in a stunning aerial map of India, in which the island of Srī Lañkā appears on the foreground (Figure 7.5).

In this large painting by Gountei (Utagawa) Sadahide (1807-1873), a painter of the Utagawa School specialized in western themes and bird-view images,

25 Mahāvamisa 1: 71-78. See Geiger (1912, 8). For a more detailed account also based on other local sources, see Wijayaratna (1987).

26 See Sundberg and Giebel (2011).

27 Lañkāvatārasūtra (Jp. Ryōgakyō) (translated by Bodhiruci in 513), in T vol. 14, no. 671. See Daisetz Teitaro Suzuki (1932); see also http://lirs.ru/do/lanka_eng/lanka-nondiacritical.htm, last accessed 30 January 2018. 


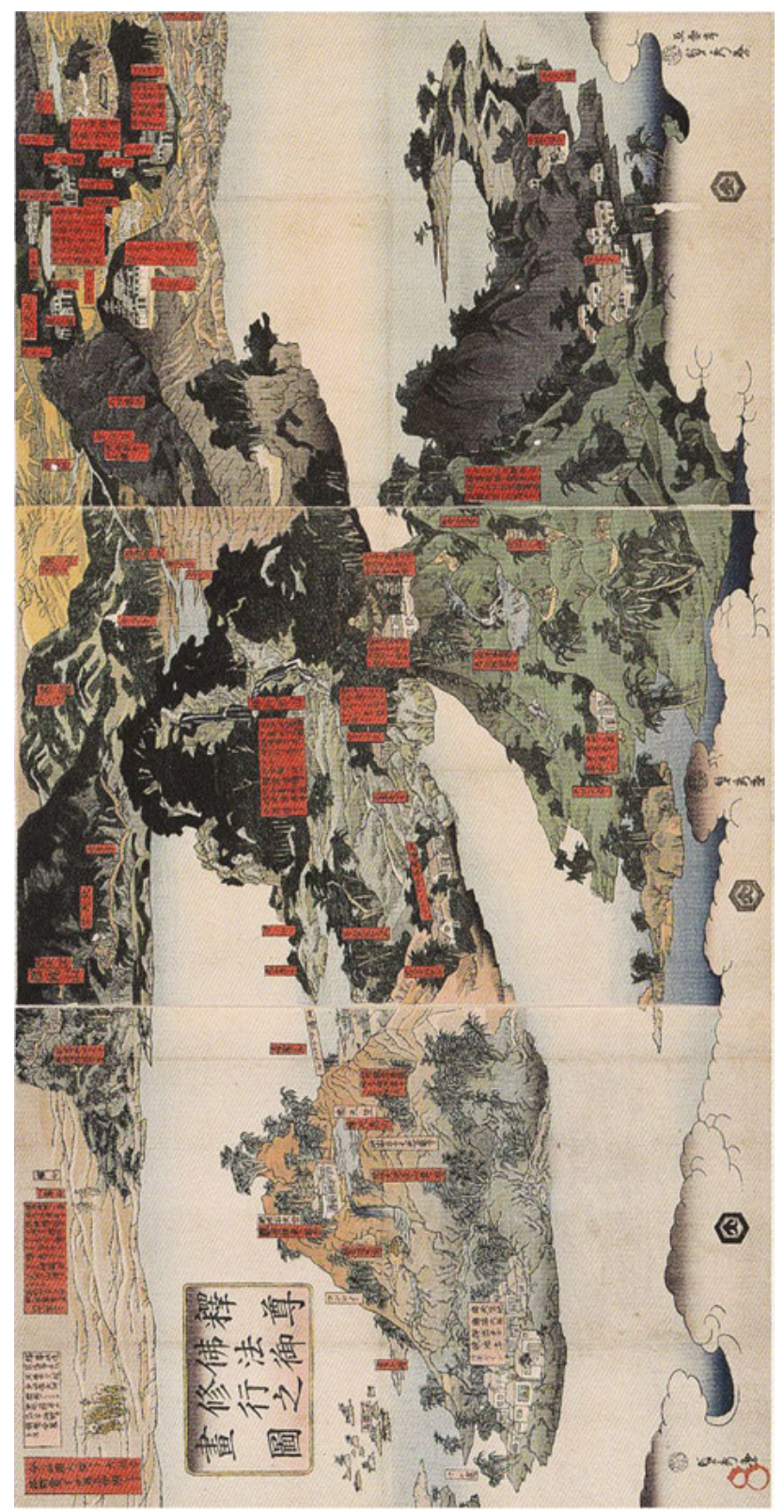

Figure 7.5: Shakuson buppō mishugyō no gazu (Painting of the [places where] Śākyamuni practiced Buddhism), 1860, by Gountei Sadahide. From Kōbe Shiritsu Hakubutsukan $(2001,58)$. 


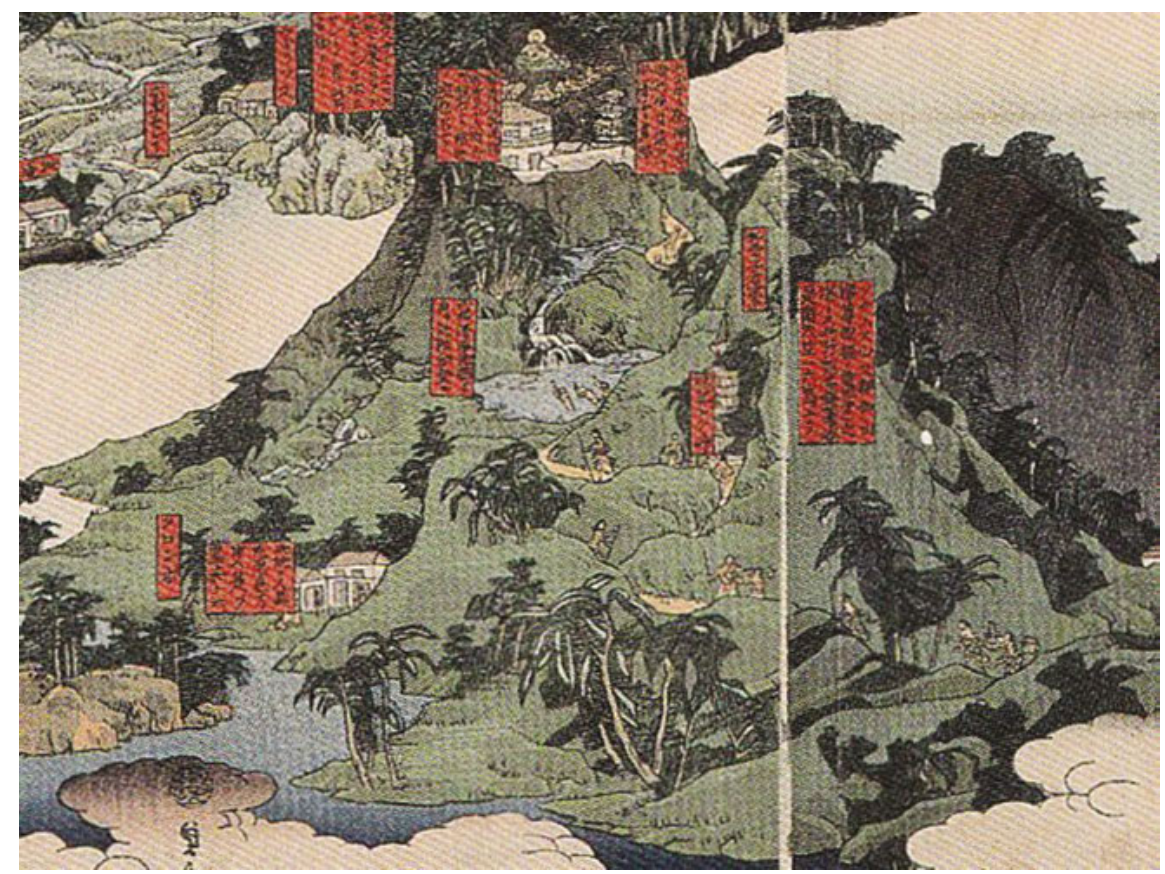

Figure 7.6: Ceylon in Shakuson buppō mishugyō no gazu (detail), by Gountei Sadahide. From Kōbe Shiritsu Hakubutsukan $(2001,58)$.

Adams Berg (Adam's Peak) is correctly equated with the Buddhist Ryōgasen (Mt. Lañkā), where Buddha is said to have exposed the Lañkāvatārasūtra; it is glossed in the map as "The most important sacred place where Sākyamuni exposed his sūtras" (Shakuson sekkyō no reichi daiichi no ba) (Figure 7.6).

We can glimpse from all this information the existence of a tradition associating the Buddha with Śrī Lañkā, and of another tradition in which Śrī Lañkā imagines itself as an ancient stalwart of Buddhism since the reign of Emperor Aśoka (third century BCE). It was not difficult, for uninformed western observers, to infer from all this that Ceylon was, if not the place of the birth and death of the Buddha, at least an important center for the propagation of Buddhism in Asia.

However, the Japanese never completely accepted Ceylon as the birthplace of Buddhism. They had a vast amount of sources clearly stating that Buddha was born and had died in the same area of north-eastern India bordering with the ancient kingdom of Magadha.

In the early nineteenth century, a Japanese geographer, Asahina Kōsei 朝夷厚生 (1748-1828), attempted to locate the sacred sites of Buddhism in 
contemporary maps of India by relying on information drawn from the travel accounts by Faxian and Xuanzang, preceding by a few decades similar attempts by western archeologists. Asahina's efforts are displayed in a map of India included in his book on India (Figure 7.7, Figure 7.8).

Analogously, the previously mentioned map by Hirata Atsutane also includes Kapilavastu (Kapirae), "birthplace of the Buddha,” and Kusinagara (Kushina), "place of Buddha's nirvana," in a relatively accurate position in north-eastern India (Figure 7.9).

Furthermore, Fukuzawa Yukichi also wrote in his previously mentioned Sekai kunizukushi: "Along this river [the Ganges] there is Allahabad, a sacred place of Sākyamuni Tathāgata. Even today, more than two hundred thousand pilgrims go there every year from all regions of India." 28 This is the same book in which Fukuzawa, as we have seen, had situated Sākyamuni's birthplace in Ceylon. It appears that, in the mind of eighteenth- and nineteenth-centuries Japanese, the boundaries of India (or, at least, of Buddhist India) were not clearly established and encompassed Ceylon as well; in addition, the location of the sacred sites of Buddhism was not known and thus only vaguely represented in maps (and besides, Allahabad is not a Buddhist sacred site).

In this way, centuries-old knowledge about the location of the Buddhist sacred sites combined with a continuing Japanese misunderstanding according to which India was a Buddhist country. Indeed, premodern Japanese do not appear to have known that Buddhism had disappeared from India in the early thirteenth century. As late as at the beginning of the nineteenth century Jiun Sonja Onkō (1718-1804) was writing that he would like to visit the sacred places on the Buddha in India - something that would have been impossible anyway, because the location of those places was not known until Markham Kittoe and Alexander Cunnigham, separately, rediscovered them in the 1840s, followed later by Lawrence Austine Waddell and Alois Führer in $1896 .^{29}$

\subsection{Conclusion}

The Japanese tended to trust the reliability of the geographical information provided by western sources as more detailed and up-to-date than their own, perhaps also because this new information was free of Buddhist apologetics; in general, the Japanese authors tried to map information from the west upon

28 Fukuzawa Yukichi, Sekai kunizukushi, p. 595a.

29 On the process of re-discovery of the sacred sites of Buddhism, see Allen (2002). 


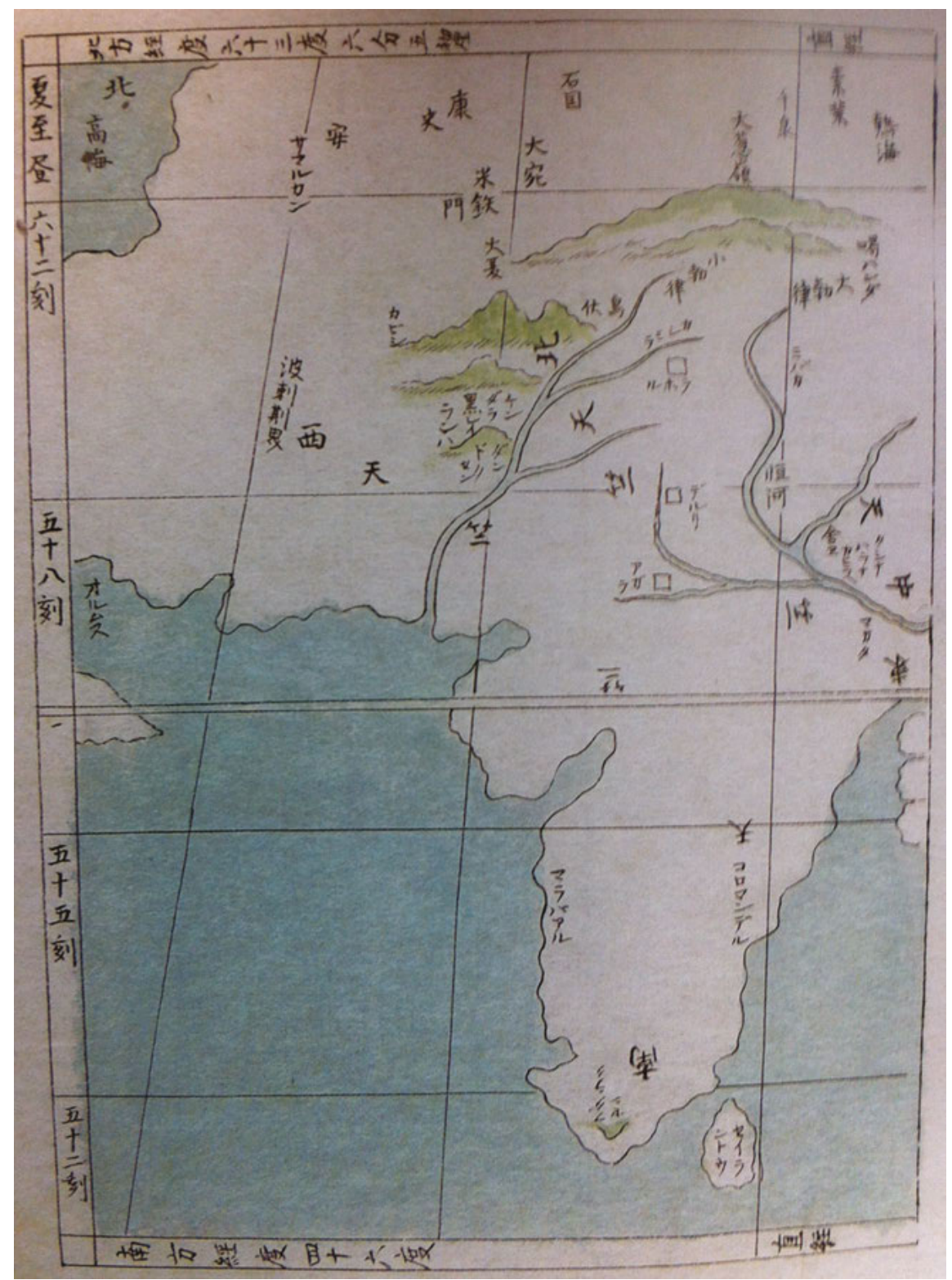

Figure 7.7: One of India's maps (Go-Tenjiku yonzu 五天箨四図) by Asahina Kōsei 朝夷厚生's Bukkoku kōshō 仏国考証, 1814. Courtesy Tokyo Metropolitan Central Library (Tōkyō Toritsu Chūō Toshokan 東京都立中央図書館). From Kondō Osamu 近藤治 (2006). Courtesy of Kyūko Shoin. 


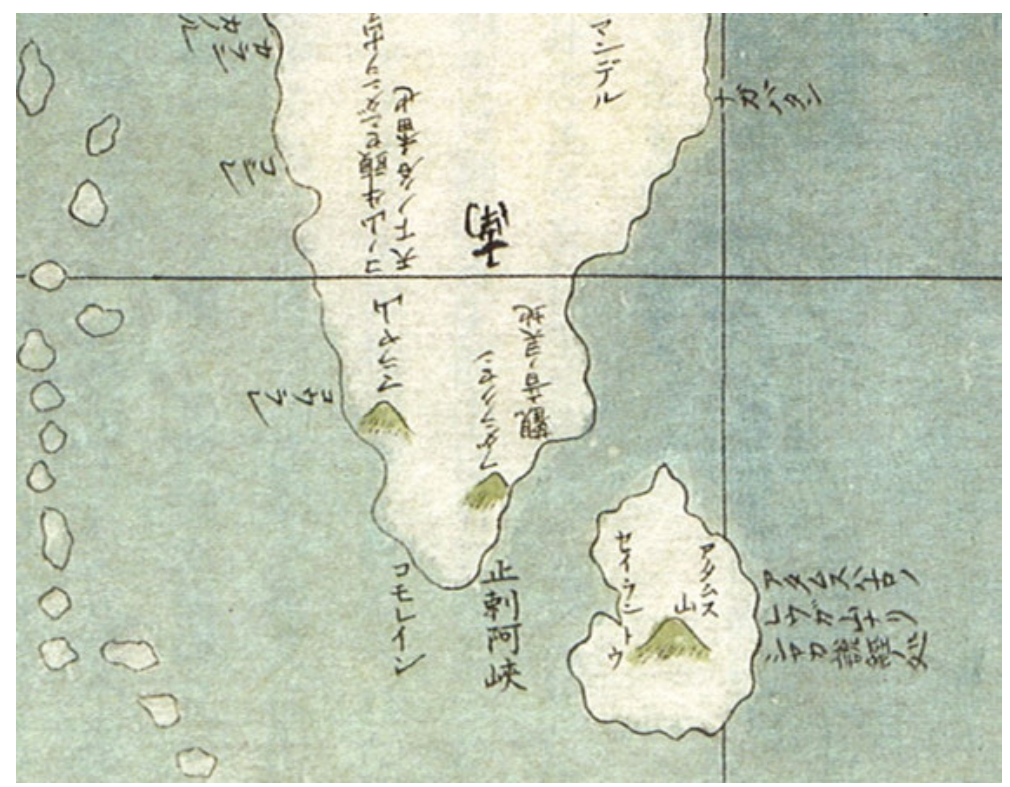

Figure 7.8: Detail from one of India‘s maps (Go-Tenjiku yonzu 五天竺四図) by Asahina Kōsei 朝夷厚生's Bukkoku kōshō 仏国考証, 1814. Courtesy Tokyo Metropolitan Central Library (Tōkyō Toritsu Chūō Toshokan 東京都立中央図書館). From Kondō Osamu 近藤治 (2006). Courtesy of Kyūko Shoin.

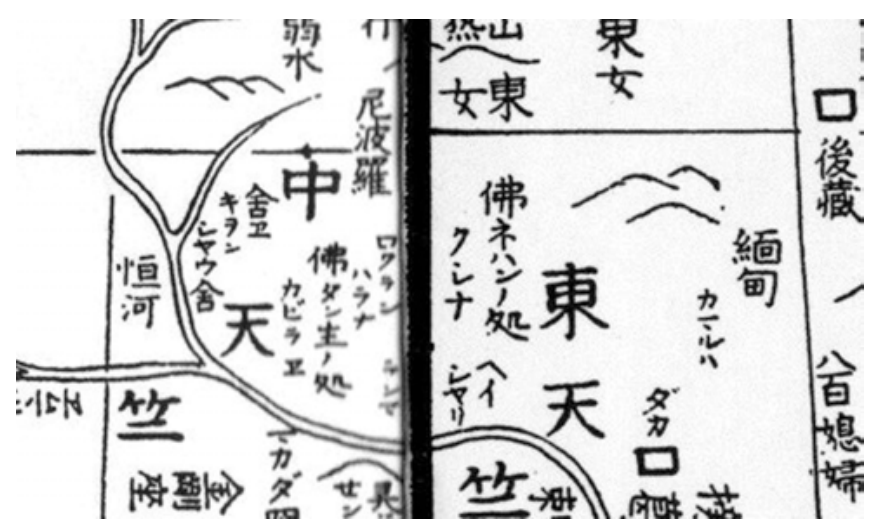

Figure 7.9: Detail of Hirata Atsutane's map of India with the sacred places of Buddhism. From Hirata Atsutane, Indo zōshi 印度蔵志, in Hirata Atsutane (1977, vol. 11, 26-27). 
their previous knowledge. In the case of Buddhism, this didn't work out well. At first, the Europeans did not envision Buddhism as a separate religious tradition, but they merged it within their broader category of Paganism/ Heathenism. Initially, this was acceptable to Japanese scholars of Dutch studies, most of whom were Confucians and therefore not interested in Buddhist apologetics and doctrines; the Japanese also believed that Buddhism was more or less diffused all over the world - an idea that somehow matched the westerners' notion of Paganism as one of the world religions. Later, toward the eighteenth century, when the Europeans began to identify Buddhism as a specific religion, they began to look for its place of origin and for information about its founder, but it took a long time for them to first acquire and then trust native knowledge. For example, the Europeans began to use the information derived from the Chinese travelers only after their texts had been translated into French - again, after they had been mediated by European academic discourses and institutions.

\section{References}

Allen, Charles. 2002. The Buddha and the Sahibs: The Men Who Discovered India's Lost Religion. London: John Murray Publishers.

Almond, Philip. 1988. The British Discovery of Buddhism. Cambridge: Cambridge University Press. App, Urs. 2012. The Cult of Emptiness. Rorschach and Kyoto: UniversityMedia.

Arai Hakuseki 新井白石. (1906) 1977. Sairan igen 采覧異言 (Collected Views on Foreign Discourses). In Arai Hakuseki zenshū 新井白石全集 (Complete Works of Arai Hakuseki). Vol. 4. Tokyo: Kokusho kankōkai 国書刊行会.

Arai Hakuseki. 1975. Seiyō kibun 西洋記聞 (Records of Matters Heard about the Western Countries). In Nihon shisō taikei 日本思想大系. Vol. 35. Tokyo: Iwanami shoten 岩波 書店.

Cesaretti, Paolo, and Silvia Ronchey, eds. 2012. Storia di Barlaam e loasaf: La vita bizantina del Buddha. Turin: Einaudi.

Daisetz Teitaro Suzuki, trans. 1932. The Lankavatara Sutra: A Mahayana Text. London: Routledge Kegan Paul.

da Lourinhã, Hilário. 1963. Vida do honrado Infante Josaphate, filho del Rey Avenir, versão de frei Hilário da Lourinhã: e a identificação, por Diogo do Couto (1542-1616), de Josaphate com o Buda. Introduction and notes by Margarida Corrêa de Lacerda. Lisboa: Junta de Investigações do Ultramar.

de la Loubère, Simon. 1691. Du Royaume de Siam. Paris: Chez la Veuve de Jean-Baptiste Coignard et Jean Baptiste Coignard.

de Lubac, Henri. 1952. La rencontre du bouddhisme et de l'Occident. Paris: Aubier. Droit, Roger-Pol. 1997. Le culte du néant: Les Philosophes et le Bouddha. Paris: Seuil. Faxian. Foguoji, also known as Kaoseng Faxian zhuan. In T. vol. 51 no. 2085, pp. 857-866. 
Fukuzawa Yukichi 福沢諭吉. 1959. Sekai kunizukushi 世界国尽 (Compendium of All Countries of the World). In Fukuzawa Yukichi zenshū 福沢諭吉全集 (Complete Works of Fukuzawa Yukichi). Vol. 2. Tokyo: Iwanami shoten 岩波書店.

Geiger, Wilhelm, trans. 1912. The Mahāvamsa or the Great Chronicle of Ceylon. London: The Pali Text Society.

Hirata Atsutane. 1977. Hirata Atsutane zenshū 平田篤扸全集. Tokyo: Meicho shuppan 名著出版. Holt, John Clifford. 2011. The Sri Lanka Reader: History, Culture, Politics. Durham: Duke University Press.

Keene, Donald. 1969. The Japanese Discovery of Europe, 1720-1830. Revised edition. Stanford: Stanford University Press.

Knox, Robert. 1681. An Historical Relation of the Island Ceylon, in the East-Indies. London: Richard Chiswell.

Kōbe Shiritsu Hakubutsukan 神戸市立博物館, ed. 2001. Ikokue no bōken: Kinsei Nihon bijutsu ni miru jōhō to gensō 異国絵の冒険一近世日本美術に見る情報と幻想. Kobe: Kōbe Shiritsu Hakubutsukan.

Kondō Osamu 近藤治, ed. 2006. Tōyōjin no Indokan 東洋人のインド観 (East Asian People’s Images of India). Tokyo: Kyūko shoin 汲古書院.

Lañkāvatārasūtra. In T vol. 14, no. 671.

Lee, Rev. Samuel, trans. 1829. The Travels of Ibn Batuta. Translated from the Abridged Arabic Manuscript Copies, preserved in the Public Library of Cambridge. London: Oriental Translation Committee.

Legge, James. (1886) 1965. A Record of Buddhistic Kingdoms. New York: Dover Publications.

Li Rongxi, trans. 1996. The Great Tang Dynasty Record of the Western Regions. BDK English Tripițaka 79. Berkeley: Numata Center for Buddhist Translation and Research.

Lopez, Donald S., Jr. and Peggy McCracken. (2014). In Search of the Christian Buddha. New York: Norton.

Nishikawa Joken 西川如見. (1944) 1988. Zōho Ka-i tsūshōkō 増補華夷通商考 (Revised and Expanded Considerations on Trade with Civilized and Barbarian Peoples). In Nihon suidokō 日本水土考 (Description of the Japanese Environment), Suido kaiben 水土解弁 (Consideration on the Natural Environment), Ka-i tsūshōkō zōho 華夷通商考増補 (Revised and Expanded Considerations on Trade with Civilized and Barbarian Peoples). Tokyo: Iwanami shoten 岩波書店.

Ozeray, Michel-Jean François. 1817. Recherches sur Buddou or Bouddou, Instituteur religieux de l'Asie orientale. Paris: Brunot-Labbé.

Polo Marco. 1920. The Travels of Marco Polo, translated by Henry Yule, edited and annotated by Henri Cordier. John Murray: London.

Rambelli, Fabio. 2014. "The Idea of India (Tenjiku) in Premodern Japan: Issues of Signification and Representation in the Buddhist Translation of Cultures." In Buddhism Across Asia. Vol. 1, edited by Tansen Sen, 259-290. Singapore: Institute of South East Asian Studies Publishing.

Sundberg, Jeffrey, and Rolf Giebel. 2011. "The Life of the Tang Court Monk Vajrabodhi as Chronicled by Lü Xiang (呂向): South Indian and Śrī Lańkān Antecedents to the Arrival of the Buddhist Vajrayāna in Eighth-Century Java and China." Pacific World, Third Series, 13 (Fall): 129-222.

Wijayaratna, Môhan. 1987. Le culte des dieux chez les bouddhistes singhalais. La religion populaire de Ceylan face au bouddhisme Theravāda. Paris: Cerf.

Xuanzang. Da Tang xiyu ji. In T vol. 51, no. 2087, pp. 932b-934c. 